\title{
Primary and secondary nucleolar organiser regions during spermatogenesis in the genus Pycnogaster
}

\author{
C. Sentis, \\ J. Santos and \\ J. Fernandez-Piqueras
}

Departamento de Biología, Unidad de Genética, Mod. C-XV, Facultad de Ciencias, Universidad Autónoma de Madrid, Cantoblanco, Madrid 28049, Spain.

Two different types of Nucleolar Organiser Regions (NORs) and associated nucleoli, which differ in morphology and the meiotic behaviour of their silver precipitates, have been found in all species of the genus Pycnogaster. The so-called primary nucleoli are present in all cells from each analysed individual, while secondary nucleoli are only present in some individuals and, within these, are not found in all the analysed cells. The chromosomal location of both types of NORs is highly conserved in this genus although the most frequently active secondary NOR is not necessarily the same in all the analysed populations or species. Distribution of secondary nucleoli among cells within each individual and among individuals from each population suggests that secondary NORs are activated according to an ordered hierarchy or nucleolar dominance. The existence of nucleolus-like structures during interkinesis-II and early round spermatids could indicate that NOR reactivation takes place at these stages. This NOR reactivation must depend on the secondary NORs, at least in the indivudals from the neo XY race of the species $P$. cucullata where half of the cells from meiosis-I on lack the neo $X$ chromosome which carries the single primary NOR in this race.

\section{INTRODUCTION}

Silver impregnation has been widely used for the identification of active Nucleolar Organizer Regions (NORs) during both mitotic and meiotic divisions (Goodpasture and Bloom, 1975; Schwarzacher et al., 1978). Nucleolar precipitates attached to the NORs can be demonstrated through the meiotic prophase-I until pachytene in vertebrate species (Hofgärtner et al., 1979; Schmid et al., 1982) or until diplotene in orthopteran species (Czaker, 1978; Rufas et al., 1985, Díez and Puertas, 1986).

During the meiotic prophase of the tettigonioid species $S$. martorelli we have described two different categories of active NORs, named primary and secondary (Fernández-Piqueras et al., $1983 b$ ). Active primary NORs can be shown in this species in all the analysed prophase-I cells, while active secondary NORs can be demonstrated only occasionally. Both types of NORs have also been found in several acridoid species by Cabrero and Camacho (1986).

The present paper studies the nucleolar activity during the spermatogenesis by silver staining in order to shed some light on the special features which characterize the active NORs found in the genus Pycnogaster.

\section{MATERIALS AND METHODS}

Adult males from the five species of the genus Pycnogaster (Bolivar, 1926) have been used for this study. The number of individuals and the sampled populations from each species are listed in table 1 .

Silver impregnation was performed as previously described (Fernández-Piqueras et al., $1982 a) ; 1 \mathrm{~g}$ of $\mathrm{AgNO}_{3}$ was dissolved in $1 \mathrm{ml}$ of a $10^{-3}$ to $10^{-4} \mathrm{M}$ sodium citrate solution adjusted with formic acid to a $p \mathrm{H}$ of 3-3.5. A drop of this solution was placed on the slide which was then incubated in a moist chamber at $60^{\circ} \mathrm{C}$ for $15-$ 30 minutes. Some slides were pretreated with $2 \times$ SSC $(0.15 \mathrm{M} \mathrm{NaCl}+0.015 \mathrm{M}$ sodium citrate $)$ at $60^{\circ} \mathrm{C}$ for 15 minutes to achieve a clear differentiation of the axial structures in the metaphase-I bivalents at previously described (Sentís et al., 1984). 
Table 1 Distribution of active sNORs in the sampled populations of the genus Pycnogaster

\begin{tabular}{|c|c|c|c|c|c|}
\hline \multirow[b]{2}{*}{ Species } & \multirow[b]{2}{*}{$\begin{array}{l}\text { Sex } \\
\text { determining }\end{array}$} & \multirow[b]{2}{*}{ Population } & \multirow[b]{2}{*}{ Individuals } & \multicolumn{2}{|c|}{ Number of individuals } \\
\hline & & & & $\begin{array}{l}\text { with active } \\
\text { sNORs at diplotene } \\
\text { (>60 per cent } \\
\text { of cells) }\end{array}$ & $\begin{array}{l}\text { without active } \\
\text { sNORs at diplotene } \\
\text { ( }<1 \text { per cent } \\
\text { of cells) }\end{array}$ \\
\hline & $\mathbf{Y} O$ & Pto. Pico (P) & 18 & 10 & 8 \\
\hline \multicolumn{6}{|l|}{ P. cucullata } \\
\hline & \multirow{2}{*}{$X Y$} & Morcuera (M) & 16 & 12 & 4 \\
\hline & & Truchas $(\mathrm{T})$ & 15 & 8 & 7 \\
\hline P. graellsi & XO & Albacete $(\mathrm{AB})$ & 14 & 12 & 2 \\
\hline P. finotii & XO & Grazalema $(G)$ & 16 & 13 & 3 \\
\hline$P$. inermis & XO & Sierra Nevada (SN) & 18 & 14 & 4 \\
\hline
\end{tabular}

\section{RESULTS}

\section{The chromosome complement}

The basic karyotype of the five species of the genus Pyncogaster consist of 28 automsomes and a $\mathrm{XO} / \mathrm{XX}$ sex determining system, which is the most common in orthopterans. The autosomes can be subdivided in one large metacentric pair (L1), five acrocentric medium sized pairs (M2-M6) and eight pairs of short acrocentric chromosomes (S7S14). The X chromosome is the second in size and it is either acrocentric in the species $P$. cucullata and $P$. graellsi, or submetacentric in three species belonging to the subgeneus Bradygaster ( $P$. inermis, P. finotii and P. sanchez-gomezi).

The species $P$. cucullata has been studied in detail in previous papers and two principal cytological races were found both differing by their sex chromosome system (XO and neo XY races). The chromosomal complement of the $\mathrm{XO}$ race consists of 28 autosomes with an $\mathrm{XO} / \mathrm{XX}$ sex chromosome determinism. Nucleolar Organizer Region in this race had been located at the proximal half of the second largest M2 pair. The neo XY race had arisen by a centric fusion between a member of the M2 pair and the X chromosome at the XO state, becoming the unfused $M 2$ in the neo Y chromosome. Nevertheless, secondary modifications during the establishment of the neo $\mathrm{XY}$ race involved the loss of the nucleolar region at the proximal region of the neo Y (FernándezPiqueras et al., 1982b, $1983 a$; Sentís et al., 1984).

\section{Silver staining during meiosis-I}

All early prophase-I cells display one or two densely stained nucleoli which have a well defined morphology (fig. 1a and 1b).
However, a percentage of cells from zygotenepachytene on additionally exhibits a second clearly distinguisable type of nucleoli in most of the analysed individuals (see table 1 and fig. $1 \mathrm{c}$ and $2 \mathrm{a}$ ). The number and chromosomal location of active NORs have been determined by the attachment of nucleoli to particular regions on the more condensed and individualised diplotene bivalents. At this stage, two types of nucleolar silver precipitates can be distinguished. The first type includes densely stained nucleoli which show a well defined morphology and are present in all diplotene cells from each analysed individual. Primary nucleoli is the name we have used to designate this type of nucleoli and similarly primary NORs (pNORs) will be used to designate those chromosomal regions which organise them.

The second type comprises smaller nucleoli which are not present in all individuals or even in all cells within a given indiviudal. These nucleoli usually display a weak staining and a diffuse morphology. We have used the terms secondary nucleoli and secondary NORs (sNORs) to designate this second type of nucleoli and the chromosomal regions which organise them, respectively.

Primary nucleoli quickly disorganise and disappear from late diplotene on, whereas secondary nucleoli are still visible at metaphase-I and even during anaphase-I as little black silver spots (fig. $1 \mathrm{~g}$ and $2 \mathrm{~h}-\mathrm{i}$ ).

Nevertheless, pretreatment with $2 \times$ SSC prior to silver staining allows one to demonstrate both primary and secondary NORs as differentiated structures of the axial elements on the metaphase-I bivalents (fig. 1h; see also Sentís et al., 1984).

Table 1 summarises the number of individuals from each population which showed at least one secondary nucleolus in more than 60 per cent of the diplotene cells and the number of individuals 

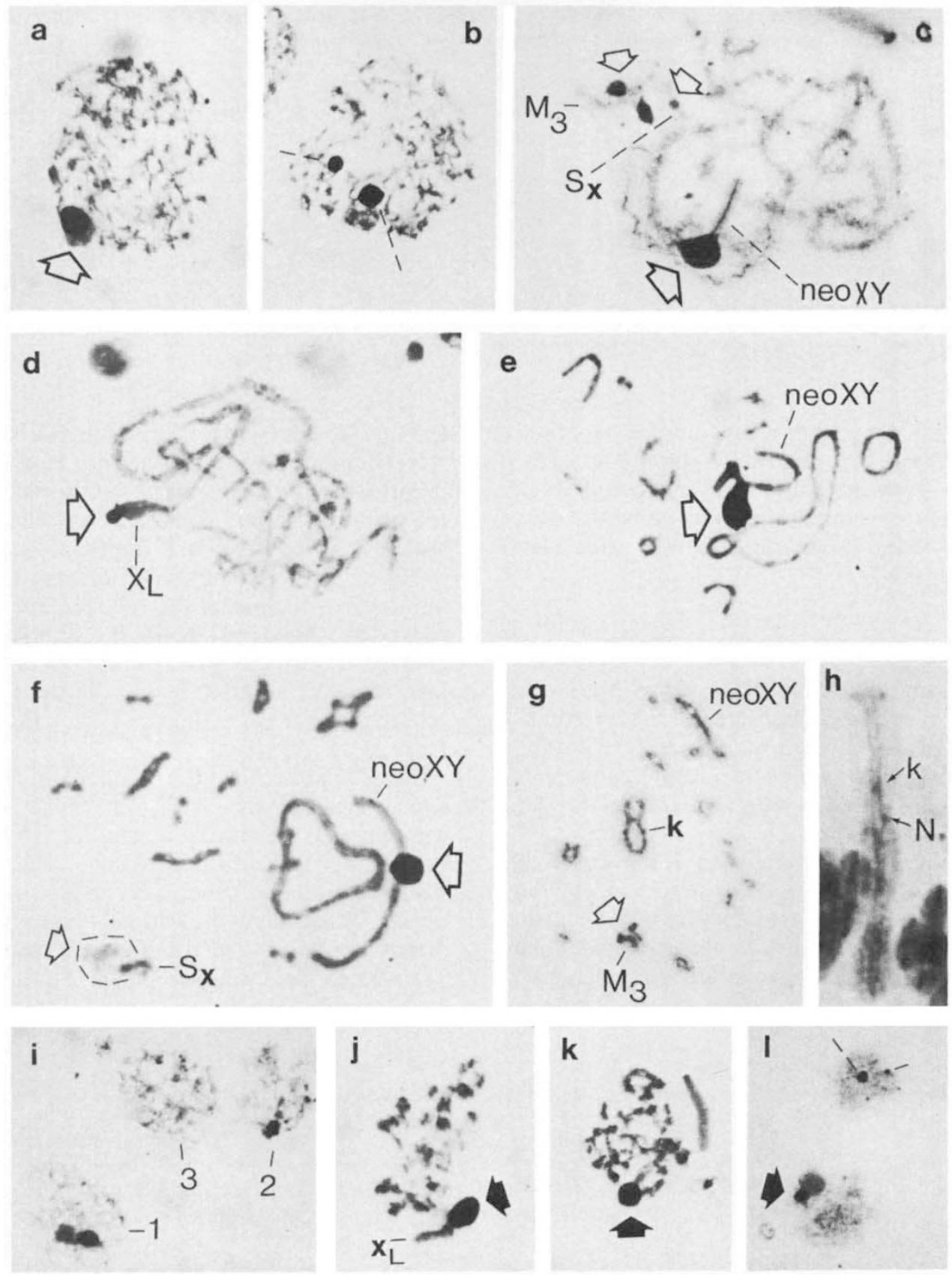

Figure 1 Neo XY race of Pycnogaster cucullata. (a-b) Early prophase-I cells with one and two nucleoli, respectively. (c) Late pachytene cell with three nucleoli. The primary nucleolus is located at the neo XY bivalent and the other two (secondary nucleoli) are placed at a medium (M3) and a short (Sx) bivalent. (d) Pachytene cell showing the primary nucleolus on the distal secondary constriction in the $X_{L}$ region of the neo $X$. (e) Diplotene cell with a primary nucleolus on the proximal secondary constriction of the neo X chromosome. (f) Diplotene cell showing a primary nucleolus located at the neo XY bivalent and a secondary one placed at a short $(\mathrm{Sx})$ bivalent. (g) Metaphase-I showing silver dots at secondary NORs in the distal region of a medium sized bivalent. $k$ denotes kinetochores. (h) Neo XY metaphase-I bivalent NORs can be visualised as differentiated structures of the axial elements (N). (i) Interkinesis-II cells. (1) with neo X and nucleolus-like structures, (2) and (3) without neo X. Only (1) and (2) show nucleolus-like precipitates. (j) Prophase-II cell with a nucleolus-like precipitate attached to the neo X chromosome. (k) Prophase-II cell with a nucleolus-like structure, but without the neo X. (1) Early round spermatids showing postmeiotical reactivation of the NOR in cells with and without the neo X chromosome. 
Table 2 Cell score (per cent) of active sNORs in those individuals with at least one active sNOR in more than 60 per cent of diplotene cells. A minimum of 50 diplotene cells per individual were examined

\begin{tabular}{|c|c|c|c|c|c|c|c|c|c|}
\hline $\begin{array}{l}\text { Number } \\
\text { of } \\
\text { active } \\
\text { sNORs }\end{array}$ & $\begin{array}{l}\text { Location } \\
\text { in the } \\
\text { chromosome } \\
\text { complement }\end{array}$ & $\frac{\text { neo } X}{T}$ & $\frac{\mathrm{ce}}{\mathrm{M}}$ & $\begin{array}{l}\text { P. cucullata } \\
\frac{\mathrm{XO} \text { race }}{\mathrm{P}}\end{array}$ & $\mathbf{A}$ & P. graellsi & P. finotii & P. inermis & $\begin{array}{l}\text { P. sanchez- } \\
\text { gomezi }\end{array}$ \\
\hline 0 & $\bar{M} x(M 3$ or $M 4)$ & $\begin{array}{r}23 \\
5\end{array}$ & $\begin{array}{l}21 \\
44\end{array}$ & $\begin{array}{l}21 \cdot 4 \\
43 \cdot 2\end{array}$ & $\begin{array}{l}22 \cdot 5 \\
42 \cdot 5\end{array}$ & $\begin{array}{l}5 \cdot 5 \\
6 \cdot 5\end{array}$ & $\begin{array}{r}4 \\
20\end{array}$ & $\begin{array}{l}24 \\
24\end{array}$ & $\begin{array}{l}28 \cdot 5 \\
46 \cdot 5\end{array}$ \\
\hline 1 & $\begin{array}{l}S x \\
M 3+M 4\end{array}$ & $\begin{array}{l}42 \\
4 \cdot 5\end{array}$ & $\begin{array}{c}6 \\
24 \cdot 5\end{array}$ & $\begin{array}{l}8 \cdot 2 \\
22\end{array}$ & $\begin{array}{l}7 \cdot 5 \\
20\end{array}$ & $\begin{array}{l}12 \\
21\end{array}$ & $\begin{array}{r}4 \\
70\end{array}$ & $\begin{array}{r}3 \\
47\end{array}$ & 21.5 \\
\hline 2 & $M x(M 3$ or $M 4)+S x$ & $25 \cdot 5$ & $4 \cdot 5$ & $5 \cdot 2$ & $7 \cdot 5$ & 55 & 2 & 2 & $2 \cdot 5$ \\
\hline
\end{tabular}

where secondary nucleoli were found in less than 1 per cent of the analysed diplotene cells. Individuals between these two categories (i.e., those displaying secondary nucleoli between 1 and 60 per cent of the diplotene cells) have not been found up to now.

\section{Number and location of active NORs}

The species of the genus Pycnogaster present a single pNOR which is located at the proximal region of the M2 bivalents (fig. $2 \mathrm{~b}-\mathrm{g}$ ) with the exception of $P$. finotti which, in addition, possesses another $\mathrm{pNOR}$ at the proximal region of the L1 bivalent (fig. 2e).

The primary NOR of the neo XY race of $P$. cucullata is located at the proximal region of the neo $\mathrm{X}$ chromosome as a consequence of the centric fusion $\mathrm{X}-\mathrm{M} 2$ originating this chromosomal race (fig. 1e and 1f; see also Fernández-Piqueras et al.,
$1983 a$ ). However, five exceptional prophase-I cells were found in one individual from Morcuera population where a single active NOR was located at the distal secondary constriction of the $X_{L}$ region (original $X$ ) of the neo X (fig. 1d).

Up to three different $s$ NORs have been found at the distal regions of the M3, M4 and one of the short $(\mathrm{Sx})$ bivalents in all the analysed species (Fig. 1c, 1f, 1g and 2b, 2d-e and 2g-i). Nevertheless, we have never observed the three sNORs to be active at the same time in a given diplotene cell from any individual.

Table 2 summarises the number and the chromosomal location of sNORs in those individuals which presented at least one active $S N O R$ in more than 60 per cent of the diplotene cells.

Exceptionally, three individuals from the XO race of $P$. cucullata showed an active sNOR at the proximal region of the $\mathrm{X}$ univalent in less than 1 per cent of their diplotene cells (fig. 2c).

Table 3 Presence of nucleolus-like structures during interkinesis-II and round spermatids in the neo XY race of $P$. cucullata

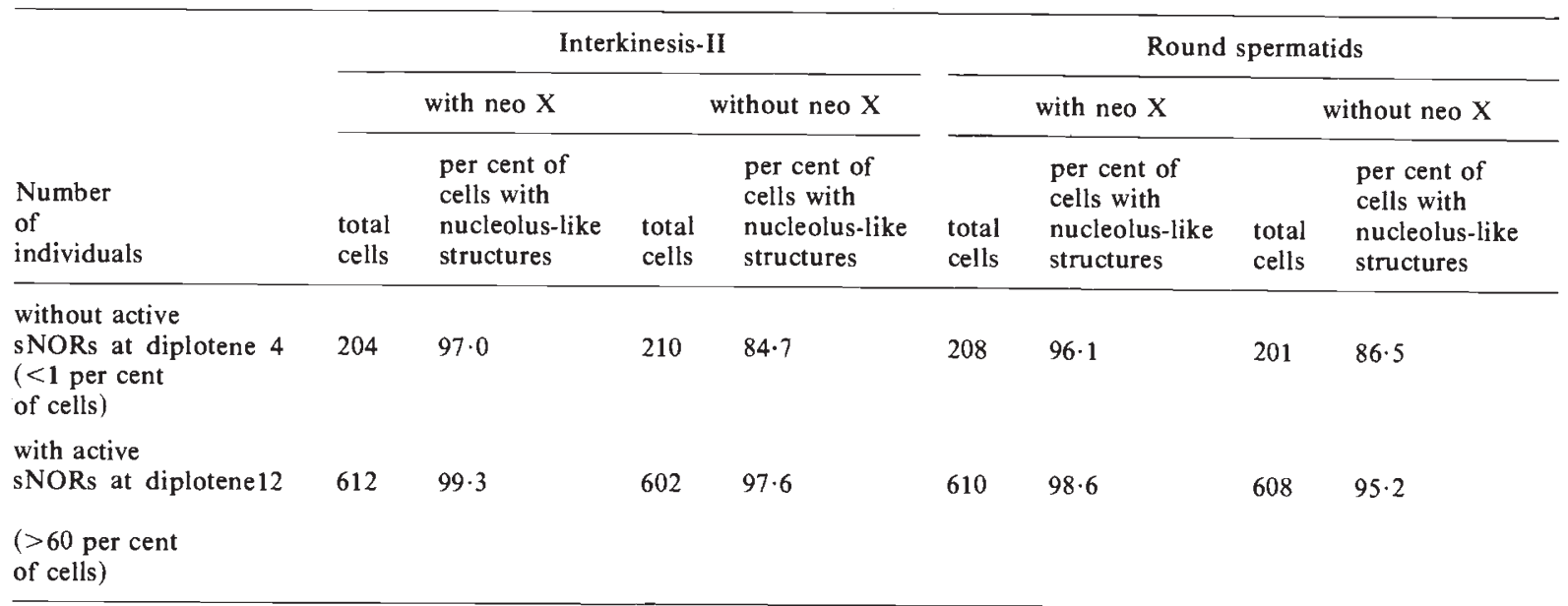



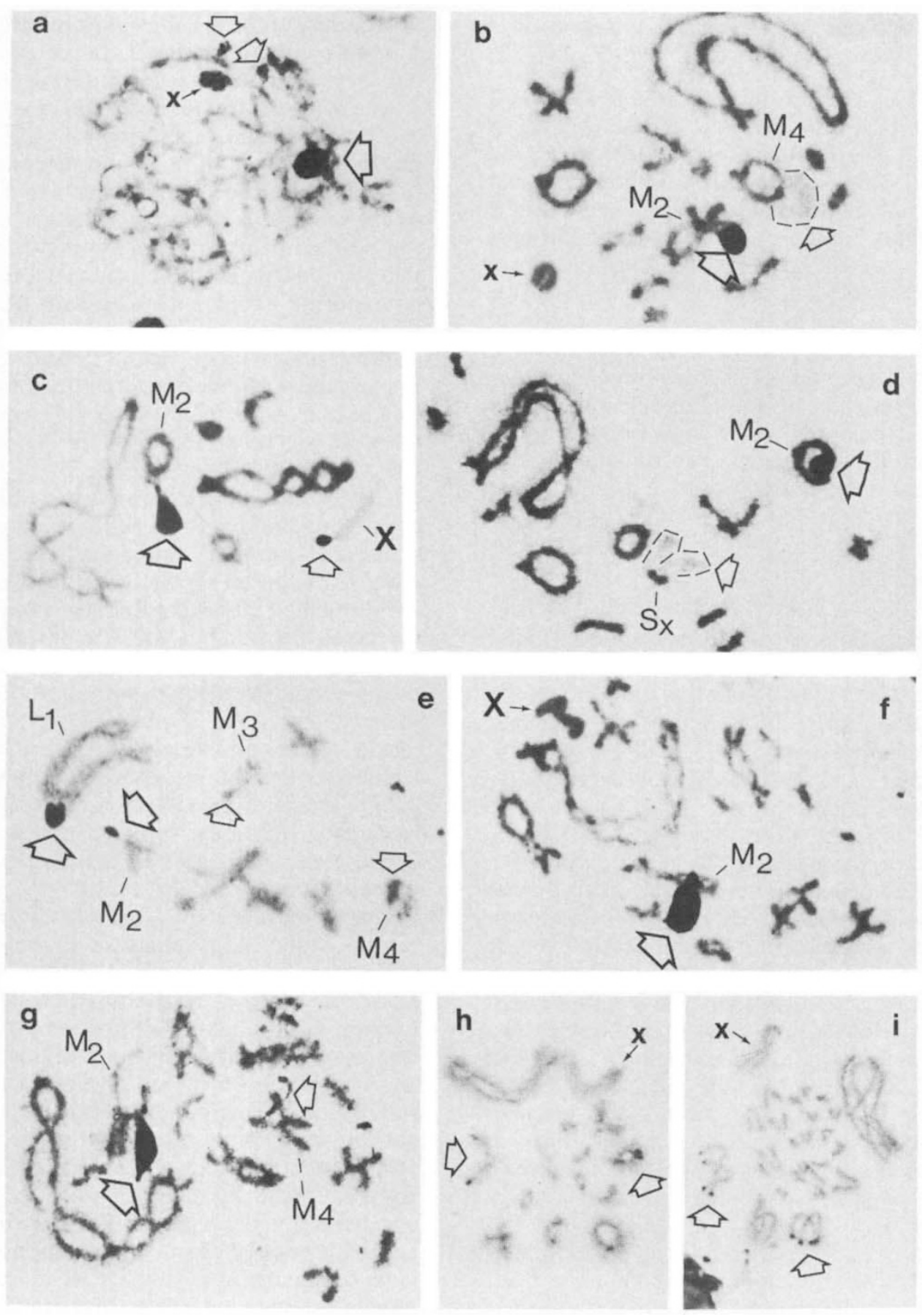

Figure 2 (a-c) XO race of Pycnogaster cucullata. (a) Pachytene cell with one primary and two secondary nucleoli. (b) Diplotene cell showing the primary nucleolus located proximally at the M2 bivalent and a secondary one at the M4 (c) Partial diplotene cell showing NOR activity in the proximal region of both the M2 bivalent and the X chromosome. (d) Pycnogaster graellsi. The primary nucleolus is located proximally at the M2 bivalent. In addition one secondary nucleolus can be distinguished at a short bivalent (Sx). (e) Pycnogaster finotti. Diplotene cell with primary nucleoli on the proximal regions of L1 and M2 bivalents and two secondary ones located at the M3 and M4 bivalents. (f) Pycnogaster sanchez-gomezi. Diplotene cell with only one primary nucleolus at the M2 bivalent. (g-i) Pycnogaster inermis. (g) Diplotene cell showing one primary and one secondary NORs. (h) Metaphase-I. Secondary nucleoli are clearly visible. (i) Anaphase-I. Secondary nucleoli can be still observed. 


\section{Silver staining during meisosis-II and early round spermatids}

Nucleolus-like structures can be seen in almost all interkinesis-II and prophase-II cells as well as in early round spermatids from all the analysed individuals. These nucleolar structures are also noticeable in the individuals from the neo $X Y$ race of $P$. cucullata despite of the fact that of the cells at these stages lack the neo $\mathrm{X}$ chromosome where the pNOR is located. However, a single silver precipitate attached to the $\mathrm{X}_{\mathrm{L}}$ region is observed when the neo $X$ is present while two or three smaller silver precipitates can be found in those nuclei which lack the neo X. These nucleolar structures can be seen in all individuals from this race, irrespective of the presence of secondary nucleoli during the first meiotic prophase (fig. $1 \mathrm{i}-1$ and table 3).

\section{DISCUSSION}

Silver impregnation constitutes a single and reliable method to study cytologically rDNA expression due to its capability to demonstrate active NORs during both mitosis and meiosis (Goodpasture and Bloom, 1975; Miller et al., 1976; Schwarzacher et al., 1978; Hofgärtner et al., 1979; Schmid et al., 1982).

Two types of nucleoli and associated NORs have been found in the species of the genus Pycnogaster during male meiosis. These types differ by the appearance and meiotic behaviour of their silver precipitates, and also more significantly because one of them is present in all cells from each individual, whereas the other type is only present in some individuals (and even so, not in all cells) from each population during prophase-I. The first type of NORs, which seem to be essential for the normal cell function, have been called primary NORs (pNORs), whereas the second type of NORs, which seem to be dispensable in at least some individuals, have been called secondary NORs (sNORs).

Secondary nucleoli can be clearly differentiated from other silver precipitates which have been previously described in the literature such as round bodies, dense bodies, $\mathrm{Ag}^{+}$-droplets or micronucleoli (Takanari et al., 1982; Hartung et al., 1983; Loidl and Greilhuber, 1983; Gosalvez et al., 1986). Secondary nucleoli, as in the case of primary ones, are seen attached to precise chromosomal locations and also their meiotic behaviour is similar to that of the standard primary nucleoli although both cycles are out of phase.
Primary nucleoli can be seen in early prophaseI, when secondary nucleoli are not yet observable, but they cannot be observed during metaphase-I, whereas secondary nucleoli remain as black silver spots at this stage (fig. $1 \mathrm{~g}$ and $2 \mathrm{~h}-\mathrm{i}$ ). The differences observed between primary and secondary nucleoli in the meiotic cycle could indicate that the activity of the sNORs is maintained longer than that of the pNORs. This is probably related to the fact that secondary nucleoli appear later than primary ones during prophase-I (compare fig. $1 \mathrm{a}$ and $1 \mathrm{~b}$ with $1 \mathrm{c}$ and $2 \mathrm{a}$ ).

The pretreatment with $2 \times \mathrm{SSC}$ prior silver impregnation allows one to improve the visualisation of both types of NORs as differentiated structures of the axial elements during metaphase-I (fig. 1h; see also Sentís et al., 1984). Gosalvez et al. (1986) have suggested that in acridoid species the pretreatment with $2 \times \mathrm{SSC}$ improves the silver staining of what they called main nucleoli and the other sites can be shown along the chromosomes with attached silver precipitates (micronucleoli). However, the number and size of nucleoli during prophase-I do not show any variation in the species of the genus Pycnogaster with or without $2 \times \mathrm{SSC}$ pretreatment prior silver staining and thus the results obtained from either of the silver staining techniques are completely valid in this species.

The chromosomal location of both primary and secondary NORs are very constant in the species of the genus Pycnogaster showing a high level of conservation during the evolution of this genus. Primary NORs are always located at the proximal regions of the M2 bivalents in all the species with the exception of $P$. finotii, which additionally possesses a pNOR at the proximal region of the L1 pair. On the other hand, secondary NORs are also usually placed at the distal regions of M3, M4 and one of the short (Sx) bivalents (fig. 2). These sNORs have been found in all species of the genus but they are not necessarily all active in the same cell. Furthermore, the most frequently activated sNOR in those diplotene cells, which only exhibit one active $\mathrm{sNOR}$, is neither the same in all species nor in all populations in a given species. Thus, the most frequently activated sNOR in the species $P$. graellsi is located at a short bivalent $(\mathrm{Sx})$, whereas an active sNOR located at Mx bivalent (M3 or M4) is the one most often found in the species $P$. sanchez-gomezi. Moreover, the active sNOR most frequently observed in the neo XY race of $P$. cucullata is located at an Sx bivalent in Truchas population, whereas it is placed at an Mx bivalent in the Morcuera population (see table 2). The most frequent combination of two active sNORs also 
depends on the species or populations and it always includes the active sNOR most frequently observed when only one active sNOR is shown.

Active sNORs must generally be dispensable for the normal cell development since there are several individuals from each population where no active sNORs can be found during prophase-I (see table 1). Nevertheless, sNORs activate in certain individuals and this activation apparently occurs according to an ordered hierarchy of nucleolar dominance. The activity of the sNORs might depend on the expression of the pNOR, since the size of primary nucleolus is considerably greater in those cells where no active sNORs can be found (compare $1 \mathrm{e}-\mathrm{f}$ and $2 \mathrm{e}-\mathrm{f}$ ).

Nucleolar dominance has been shown in several groups of species after the analysis of interspecific hybrids (Miller et al., 178). In the common bread wheat, Flavell and Martini (1982) have reported that the number of active NORs per cell can be influenced by the possible competitive action among NORs or by the action of some genes which can modify or suppress NOR activity. More recently, Diez and Puertas (1986) have suggested that the bivalent distribution of the active NORs in the orthopteran Locusta migratoria was not random, and the activation of NORs seems to behave as if by successive rounds of activation and so an interval could exist between the formation of each NOR in a single cell.

The fact that all diplotene cells show a primary nucleolus in the species of the genus Pycnogaster could indicate that there is a single "dominant NOR" (primary NOR) with the exception of the species $P$. finotii where two primary nucleoli can be seen in all prophase-I cells. Secondary NORs could be another category of NOR which sometimes appear to be "latent" but can be activated in certain conditions by successive rounds of activation according to an ordered sequence which can differ between populations or species in the genus.

Nevertheless, nucleolar precipitates can be observed at a very low rate in the proximal region of the X chromosome in the XO race of $P$. cucullata. Thus, other possible "latent NORs", in addition to those described, could also exist in the genus Pycnogaster.

Five exceptional cells were found in a single male of the neo XY race of $P$. cucullata which displayed a single active NOR at the distal secondary constriction of the $X_{L}$ arm of the neo $X$ bivalent (fig. 1d). This fact could indicate the existence of a new "latent NOR" at this position where two silver spots can be seen throughout meiosis in most of the individuals analysed so far (Sentís et al., 1984).

Silver staining during the second meiosis in the genus Pycnogaster reveals that nucleolus-like structures can be seen in all species during interkinesis-II and prophase-II (fig. 1i-k) and they decrease in size up to anaphase-II. Similar nucleolus-like structures can also be seen in early round spermatid nuclei presumably corresponding to a postmeiotical reactivation of NORs already described in other species (Hofgärtner et al., 1979; Schmid et al., 1982). Nucleolar precipitates and/or $\mathrm{Ag}^{+}$NORs throughout male meiosis have also been described in other species (Di Castro et al., 1983; Loidl and Greilhuber, 1983; Cuñado et al., 1986) including orthopteroid insects (Satya-Prakash and Pathak, 1984; Santos et al., 1987). The visualisation of nucleolus-like structures during interkinesis-II and prophase-II does not necessarily imply transcriptional activity of rDNA at these stages. It might be a decondensation of material which was packed at the NOR during the first meiotic division or aggregation of previously dispersed material at the NOR. Nevertheless, it is very likely that NOR reactivation really occurs in the period between the two meiotic divisions as Dickinson and HeslopHarrison (1970) have already pointed out in plants. The RNA synthetic activity observed by Henderson (1964) and Das et al. (1965) during both interkinesis and early spermatids in grasshoppers could reinforce this hypothesis.

It may be presumed that this reactivation must generally involve the primary NOR in the species of the genus Pycnogaster. However, the vast majority of the interkinesis and early spermatid nuclei in the neo XY race of $P$. cucullata show nucleoluslike structures, despite the fact that half of them lack the neo $\mathrm{X}$ chromosome, where the primary NOR is located (table 3 ).

If NOR reactivation at interkinesis-II or early round spermatids is essential for the normal development of spermatogenesis, secondary NORs will become essential in some particular cases, as the neo XY race of $P$. cucullata.

In conclusion, we think that different types of Nucleolar Organiser Regions could coexist in the same species and activation of NORs must be under unknown cellular controls proceeding in an ordered way which is specific for each population or species of the genus Pycnogaster.

Acknowledgements We wish to thank Guillermo Visedo for aid with this manuscript. This work was supported by a grant from the Spanish CAICYT No. PR84-0364. 


\section{REFERENCES}

BOlivar, I. 1926. La subfamilia Pycnogastrinae, Eos, Rev. Esp. Entomol., II, 424-463.

CABRERO, J. AND CAMACHO, J. P. M. 1986. Cytogenetic studies in gomphocerine grasshoppers. II. Chromosomal location of active nucleolar organizing regions. Can. J. Genet. Cytol. $28,540-544$.

CUÑAdo, N., CERMEÑo, M. C. AND ORELlANA, J. 1986. Nucleolar organizer activity at meiosis in wheat-rye hybrids plants. Can. J. Genet. Cytol., 28, 227-234.

CZAKER, R. 1978. Silver staining in transcriptionally active NORs of meiotic and mitotic cells in Acheta domesticus L. (Orthoptera). Chromosoma, 68, 187-193.

DAS, N. K., SIEGEL, E. P. AND ALFERT, M. 1965. Synthetic activities during spermatogenesis in the locust. J. Cell Biol., 25, 387-395.

DI CASTRO, M., PRANTERA, G., CIPRIANI, L. AND ROCCHI, A. 1983. Silver staining analysis of nucleolar organizer activity during spermatogenesis of Asellus aquaticus (Crustacea, Isopoda). Genetica, 60, 163-166.

DICKINSON, H. G. AND HESLOP-HARRISON, J. 1970. The ribosome cycle, nucleoli and cytoplasmic nucleoloids in the meiocytes of lilium. Protoplasma, 69, 187-200.

DIEZ, M. AND PUERTAS, M. J. 1986. Quantitative analysis of the formation of nucleoli in Locusta migratoria. Can J. Genet. Cytol., 28, 207-218.

FER NANDEZ-PIQUERAS, J., RODRIGUEZ CAMPOS, A., SENTIS CASTAÑO, C. AND ROJO GARCIA, E. 1982a. Differential staining of the $\mathrm{X}$ chromosome during meiosis of Orthoptera by silver impregnation procedure. Chromosoma, 85, 707711.

FERNANDEZ-PIQUERAS, J,, RODRIGUEZ CAMPOS, A., SENTIS CASTAÑo, C. AND WANdodosel JuRAdo, F. 1982 b. Pycnogaster cucullata (Charp): A polytypic species of tettigoniodidea with $\mathrm{XO}$ and neo $\mathrm{XY}$ sex determination. Heredity, 48, 147-150.

FERNANDEZ-PIQUERAS, J., RODRIGUEZ CAMPOS, A., SENTIS CASTAÑO, C. AND ROJO GARCIA, E. 1983a. Sex chromosome evolution in the polytypic species Pycnogaster cucullata. Heredity, 50, 217-223.

FERNANDEZ-PIQUERAS, J., RODRIGUEZ CAMPOS, A., SENTIS CASTAÑo, C. AND ROJO GARCIA, E., 1983b. Chromosomal location of the active NORs in the Stereopleuras martorelli complex. Genetica, 61, 9-12.

FLAVELL, R. B. AND MARTINI, G. 1982. The gen etic control of nucleolus formation with special reference to common bread-wheat. In Society Experimental Biology Symposium. Cambridge Univ. Press.

GOODPASTURE, C. AND BLOOM, S. E. 1975. Visualization of nucleolar organizer regions in mammalian chromsomes using silver staining. Chromosoma, 53, 37-50.

GOSALVEZ, J., DE LA TORRE, J., GARCIA DE LA VEGA, C. AND LOPEZ-FERNANDEZ, C. 1986. The effect of double-strength standard saline citrate on silver staining. I. Nucleoli and micronucleoli in the somatic and germ line of the grasshopper Arcyptera fusca (Orthoptera). Can. J. Genet Cytol., 28, 219-226.

hARTUNG, M., KEEliNG, J. W., PATEL, C., BORROW, M. AND STAHL, A., 1983. Nuecleoli, micronucleoli and nucleoluslike structures in human oocytes at meiotic prophase-I studied by the silver NOR technique. Cytogenet. Cell Genet. $35,2-8$.

HENDERSON, S. A., 1964. RNA synthesis during male meiosis and spermatogenesis. Chromosoma, 15, 345-366.

HOFGARTNER, F. J., SCHMID, M., KRONE, W., ZENZES, M. T. AND ENGEL, W. 1979. Pattern of activity of nucleolus organizer during spermatogenesis in mammals as analyzed by silver staining. Chromosoma, 71, 197-216.

LOIDL, J. AND GREILHUBER, J. 1983. Structural changes of $\mathrm{Ag}$-stained nucleolus organizing regions and nucleoli during meiosis in Allium flavum. Can. J. Genet. Cytol., 25, 524-529.

MILlER, D. A., DEV, V. G., TANTRAVAHI, R. AND MILlER, O. J. 1976. Suppression of human nucleolus organizer activity in mouse-human somatic hybrid cells. Exp. Cell. Res., 101, 235-243.

MILLER, D. A., DEV, V. G., TANTRAVAHI, R., CROCE, C. M. AND MILlER, O. J. 1978. Human tumor and rodent-human hybrid cells with an increased number of active human NORs. Cytogenet. Cell Genet., 21, 33-41.

RUFAS, J. S., ESPONDA, P. AND GOSALVEZ, J. 1985. NOR and nucleolus in the spermatogenesis of acridoid grasshoppers. Genetica, 66, 139-144.

SANTOS, J., SENTIS, C. AND FERNANDEZ-PIQUERAS, J. 1987. Pattern of nucleolar organizer region activity during male meiosis in Callicrania seoanei (Orthoptera) as analyzed by silver staining: evidences for possible reactivation in the period between the two meiotic divisions. Genome, 29, (in press).

SATYA-PRAKASH, K. L. AND PATHAK, S. 1984. Silver staining pattern of male meiosis in the house cricket. J. Hered., 75 , 319-320.

SCHMID, M., LOSER, C., SCHMIDTKE, J. AND ENGEL, W. 1982 Evolutionary conservation of a common pattern of activity of nucleolus organizers during spermatogenesis in vertebrates. Chromosoma, 86 149-179.

SCHWARZACHER, H. G., MIKELSAAR, A. V. AND SCHNEDL, W. 1978. The nature of the Ag-staining of nucleolus organizer regions. Electron and light-microscopic studies on human cells in interphase, mitosis and meiosis. Cytogenet. Cell Genet., 20, 24-39.

SENTIS, C., STOCKERT, J. C. AND FERNANDEZ-PIQUERAS, J. 1984. Morphology of the axial structures in the neo XY sex bivalent of Pycnogaster cucullata (Orthoptera) by silver impregnatiation. Chromosoma, 90, 317-321.

TAKANARI, H., PATHAK, S. AND hSU, T. C. 1982. Dense bodies in silver stained spermatocytes of the Chinese hamster: behaviour and cytochemical nature. Chromosoma, 86, 359373. 